\title{
A CONVENIENT HIV SCREENING: ORAL RAPID TEST REVIEW OF LITERATURE
}

Devi Nasution*,Tenny Setiani Dewi ${ }^{* *}$

\section{Keywords: HIVIAIDS, HIV screening, oral rapid

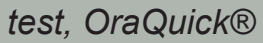

\section{ABSTRACT}

Background: HIV testing is crucial in identifying and initiating the treatment of HIVIAIDS. In recent years, the Oral Rapid Tests (ORT) has become one of the most popular tests based on saliva. This paper aims to present the response from research subjects who took the ORT using OraQuick®.

Discussion: A total of 2657 studies was obtained. Finally, 21 articles matched to our review. The 21 included studies showed the advantages of ORT such as comfortable $91 \%$, easy to use $76 \%$, quick results $54 \%$, preferred choice $67 \%$, maintains confidentiality $54 \%$ and other reasons. Our reviewed studies demonstrated the consistent high acceptability of the oral rapid test in HIV.

Conclusion: The comforts stem from ORT with OraQuick ${ }^{\circledR}$ are being contributed by its easy to use characteristic and non-blood-withdrawn comfortable method

\section{INTRODUCTION}

In 2017, globally people living with HIV reached 36.9 million. ${ }^{1}$ Strategies to combat HIVIAIDS are based on early detection of HIV infection and appropriate treatment planning. In general conventional strategy for HIV testing is the use of the specific antibody screening such as the ELISA test. ${ }^{1,2,3}$ This cannot always be done in a developing country because it requires expensive customized laboratory equipment with expert staffs. ${ }^{2,4}$ Also those who are at high risk of HIV infection are sometimes constrained in the process of blood-taking due to perceived pain from the injection. ${ }^{5}$

In 2004, a rapid HIV-antibody-based test named OraQuick ${ }^{\circledR}$ advance rapid HIV-1/2 (OraSure Technologies Inc, PA, USA) was approved by the US Food and Drug Administration (FDA) to use with specimens of oral mucosal transudate. ${ }^{6}$ In recent years, ORT has become one of the most popular saliva-based tests. It is more acceptable to most patients because of the non-invasive specimen collection, quick result, and ease of use. ${ }^{7,8}$ Some even promoted the OraQuick $®$ for a home self-testing of HIV. . $^{6,9}$

Unfortunately in Indonesia, ORT is highly unpopular and in general is a strange concept for medical and dental practitioners even though the ORT is more appealing to invite people to screen for early HIV infection. Especially in areas that are difficult to reach and laboratory facilities are not available. This study aims to present the advantages of ORT using OraQuick $₫$ to serve as a supporting literature in the use of OraQuick ${ }^{\circledR}$ for the dental practitioner.

\section{LITERATURE REVIEW}

The literature was conducted according to the Preferred Reporting Items For Systematic Reviews and Meta-Analyses Protocols (PRISMA-P) 2015 statement. $^{10}$

Based on the PRISMA guidelines, 1 focused PICO (population, intervention, comparison, and outcome) question were constructed:

*Oral Medicine Specialist Program, Faculty of Dentistry, Universitas Padjadjaran, Dr. Hasan Sadikin Hospital, Bandung-Indonesia, **Oral Medicine Department, Faculty of Dentistry, Universitas Padjadjaran, Dr. Hasan Sadikin Hospital, Bandung-Indonesia

Korespondensi: devinasution1989@gmail.com 
1) What are the advantages of ORT compared to blood tests?

Pubmed, Science Direct, the Cochrane Library and the Global Health Database were systematically searched for matching manuscripts and a comprehensive Google search was performed for gray literature. Search terms included 'Oral Rapid Test' AND 'HIV' OR 'Self-test' OR 'Home-test'. We conducted the search without date restriction from 2010 until August 1st, 2018 in English language references available.

Inclusion criteria. Full-text articles were included regardless of the time period of study and year of publication.

The studies included had to be an original article published in scientific journals, randomized control trial, cross-sectional or cohort studies, comparative studies, only humans and written in the English language.Individuals with HIV infection or not. No restriction for HIV diagnosis classification criteria was applied.

We expect this ORT to become a new breakthrough as technology develops as an HIV fast test that is accurate and in great de- mand by the public.

Exclusions criteria. The quality of journals that are not included in the Scopus index and the case report studies. Literature presented outside of English was also excluded from this study.

The quality of the reference from this study uses Scopus with results consisting of Q1 in 15 studies, Q2 in 4 studies, and Q3 in 2 studies. Follow the procedures according to Joanna Briggs Institue $(\mathrm{JBI})$ to see the bias from the reviewed literature. ${ }^{11}$

In determining the results of this study, we categorize groups based on their respective types of research. The outcome of the preferred Oral Rapid Test HIV from the included studies was presented as a percentage displayed in the form of tables (Table 3 ).

The search strategy resulted in 2657 articles, which then filtered to finally got 21 publications that were eligible for our review (Figure 1 ). We reviewed the quality of these 21 studies, 15 studies were in quartile 1 (Q1), 4 research on Q2, and 2 research on Q3 (Table 1).

There are 14 cross-sectional and 5 research

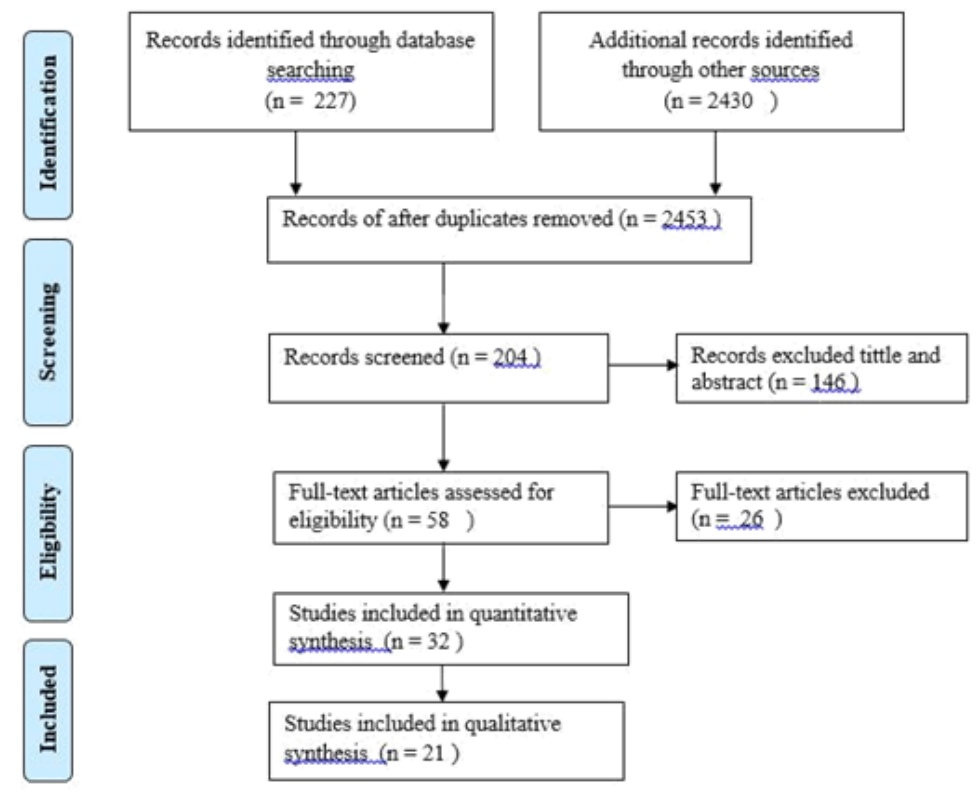

Figure 1. Flow diagram of the literature search, according to the Preferred Reporting Items for Systematic Reviews and Meta-Analyses (PRISMA). 
studies with descriptive cross-sectional, 1 articles with cohort studies, and 1 articles with randomized controlled trials. All research is published between 2010 and 2018 (Table 1,2).

Participants liked and chose Oral Rapid Test to screen early on HIV detection mainly due to its practical and painless reasons. The 21 included studies showed the advantages of ORT such as comfortable $91 \%$, easy to use $76 \%$, quick results $54 \%$, preferred choice $67 \%$, maintains confidentiality $54 \%$ and the others reason like a self-testing at home, enable frequent

Tabel 1. Studies included in the review

\begin{tabular}{|c|c|c|c|c|c|}
\hline No & Author & Tittle & Location & Years & Quality \\
\hline 1 & Bradley, et al. $^{12}$ & $\begin{array}{l}\text { Acceptability of oral rapid HIV testing at dental clinics in } \\
\text { communities with high HIV prevalence in South Florida }\end{array}$ & $\begin{array}{l}\text { South } \\
\text { Florida }\end{array}$ & 2018 & Q1 \\
\hline 2 & Sharma $\mathrm{P}$, et al. ${ }^{13}$ & $\begin{array}{l}\text { Is it feasible to use an oral-fluid based rapid test } \\
\text { facilitated by frontline workers to improve HIV screening } \\
\text { of Pregnant women in Indian Rural settings? }\end{array}$ & India & 2018 & Q2 \\
\hline 3 & Martin I.B, et al. ${ }^{14}$ & $\begin{array}{l}\text { Performance of and preference for oral rapid HIV testing } \\
\text { in the Bahamas }\end{array}$ & Bahamas & 2018 & Q3 \\
\hline 4 & Nangendo J, et al. ${ }^{15}$ & $\begin{array}{l}\text { Diagnostic accuracy and acceptability of rapid HIV oral } \\
\text { testing among adults attending an urban public } \\
\text { health facility in Kampala, Uganda }\end{array}$ & $\begin{array}{l}\text { Kampala, } \\
\text { Uganda }\end{array}$ & 2017 & Q1 \\
\hline 5 & Pando, et al. ${ }^{16}$ & $\begin{array}{l}\text { High Acceptability of rapid HIV self-testing among a } \\
\text { diverse sample of MSM from Buenos Aires, Argentina }\end{array}$ & Argentina & 2017 & Q1 \\
\hline 6 & Irarrazabal, et al. ${ }^{17}$ & $\begin{array}{l}\text { Predictors of readiness for oral rapid HIV testing by } \\
\text { Chilean health care providers }\end{array}$ & Chile & 2016 & Q3 \\
\hline 7 & Sarkar A,et al. ${ }^{18}$ & $\begin{array}{l}\text { Feasibiliy of Supervised self-testing using fluid-based } \\
\text { HIV rapid testing method : a cross-sectional, mixed } \\
\text { method study among pregnant women in rural India }\end{array}$ & India & 2016 & Q1 \\
\hline 8 & Kurth $\mathrm{AE}$, et al. ${ }^{19}$ & $\begin{array}{l}\text { Accuracy and Acceptability of Oral Fluid HIV Self- } \\
\text { Testing in a General Adult Population in Kenya }\end{array}$ & Kenya & 2016 & Q1 \\
\hline 9 & $\begin{array}{l}\text { Platteau Tom, et } \\
\text { al. }^{20}\end{array}$ & $\begin{array}{l}\text { Swab2know: An HIV-Testing Strategy Using Oral Fluid } \\
\text { Samples and Online Communication of Test Results for } \\
\text { Men Who Have Sex With Men in Belgium }\end{array}$ & Belgium & 2015 & Q1 \\
\hline 10 & Marley, et al. ${ }^{21}$ & $\begin{array}{l}\text { Introducing rapid oral-fluid HIV testing among high risk } \\
\text { populations in Shandong, China: feasibility and } \\
\text { Challenges }\end{array}$ & $\begin{array}{l}\text { Shandong, } \\
\text { China }\end{array}$ & 2014 & Q1 \\
\hline 11 & Pant Pai,et al. ${ }^{22}$ & $\begin{array}{l}\text { Will an Unsupervised Self-Testing Strategy Be Feasible } \\
\text { to Operationalize in Canada? Results from a Pilot Study } \\
\text { in Students of a Large Canadian University }\end{array}$ & Canada & 2014 & Q2 \\
\hline 12 & Irarrazabal, et al. ${ }^{23}$ & $\begin{array}{l}\text { Oral rapid test : an alternative to traditional HIV } \\
\text { screening in Chile }\end{array}$ & Chile & 2013 & Q2 \\
\hline 13 & $\begin{array}{l}\text { Xun Huanmiao, et } \\
\text { al. }^{24}\end{array}$ & $\begin{array}{l}\text { Factors Associated with Willingness to Accept Oral Fluid } \\
\text { HIV Rapid Testing among Most-at-Risk Populations in } \\
\text { China }\end{array}$ & China & 2013 & Q1 \\
\hline 14 & Xu Yunan, et al. ${ }^{25}$ & $\begin{array}{l}\text { Willingness to Use the Oral Fluid HIV Rapid Test among } \\
\text { Men Who Have Sex with Men in Beijing, China }\end{array}$ & $\begin{array}{l}\text { Beijing, } \\
\text { China }\end{array}$ & 2013 & Q1 \\
\hline 15 & Donnel-Fink,et al. ${ }^{26}$ & $\begin{array}{l}\text { Acceptability of Fingerstick vs. Oral Fluid HIV Testing: } \\
\text { Results from the Universal Screening for HIV-infection in } \\
\text { the Emergency Room (USHER-Phase II) Randomized } \\
\text { Controlled Trial }\end{array}$ & Boston & 2013 & Q1 \\
\hline 16 & Jain Sachin,et al. ${ }^{27}$ & $\begin{array}{l}\text { Seroprevalence Study Using Oral Rapid HIV Testing In } \\
\text { A Large Urban Emergency Department }\end{array}$ & $\begin{array}{l}\text { Chicago, } \\
\text { USA }\end{array}$ & 2012 & Q1 \\
\hline 17 & $\mathrm{Ng} \mathrm{OT}$, et al. ${ }^{28}$ & $\begin{array}{l}\text { Accuracy and User-Acceptability of HIV Self-Testing } \\
\text { Using an Oral Fluid-Based HIV Rapid Test }\end{array}$ & Singapore & 2012 & Q1 \\
\hline 18 & Choko, et al. ${ }^{29}$ & $\begin{array}{l}\text { The Uptake and Accuracy of Oral Kits for HIV Self- } \\
\text { Testing in High HIV Prevalence Setting: A Cross- } \\
\text { Sectional Feasibility Study in Blantyre, Malawi }\end{array}$ & $\begin{array}{l}\text { Blantyre, } \\
\text { Malawi }\end{array}$ & 2011 & Q1 \\
\hline 19 & Gaydos, et al. ${ }^{30}$ & $\begin{array}{l}\text { Will Patients "Opt in" to Perform Their Own Rapid HIV } \\
\text { Test in the Emergency Department? }\end{array}$ & $\begin{array}{l}\text { Baltimore, } \\
\qquad \text { MD }\end{array}$ & 2011 & Q1 \\
\hline 20 & Chen $\mathrm{Y} M$, et al. ${ }^{31}$ & $\begin{array}{l}\text { Australian men who have sex with men prefer rapid oral } \\
\text { HIV testing over conventional blood testing for HIV }\end{array}$ & Australia & 2010 & Q2 \\
\hline 21 & Sena, et al. ${ }^{32}$ & $\begin{array}{l}\text { Feasibility and Acceptability of Door-to-Door Rapid HIV } \\
\text { Testing Among Latino Immigrants and Their HIV Risk } \\
\text { Factors in North Carolina }\end{array}$ & $\begin{array}{l}\text { North } \\
\text { Carolina }\end{array}$ & 2010 & Q1 \\
\hline
\end{tabular}


testing, should sold in public, recommended to use for community, importance, willingness to pay and benefited (Table 3).

The use of this device is only in developing countries. The absence of calibration of this tool by default and according to evidence-based medicine.

There is a possibility of literature in other languages than English that discusses the same topic as this paper. This paper also collects data from various developing countries with high risk prevalence and does not cover all countries including Indonesia.

\section{DISCUSSION}

ORT is the latest technological breakthrough that has been internationally recognized and has been approved by the USA FDA. ${ }^{33}$ Where the accuracy has been tested and carried out by various developing countries with the results of sensitivity and specificity that are almost equal to conventional tests such as ELISA. ${ }^{6,34}$

Some of this research was carried out on populations at high risk of HIV and also pregnant women because it is very high risk to transmit infection to surrounding communities,

Tabel 2. The population and type of research studies

\begin{tabular}{|c|c|c|c|}
\hline No & Author & Population & Study Design \\
\hline 1 & Bradley, et al & 600participants & Cross Sectional \\
\hline 2 & Sharma $P$, et al & 947 participants & $\begin{array}{l}\text { Descriptive Cross } \\
\text { Sectional }\end{array}$ \\
\hline 3 & Martin I.B, et al & $\begin{array}{l}252 \text { participants. Men : } 94(37,3 \%) \text {, Women : } 158 \\
(62,7 \%) \text {. Median age : } 26 \text { (IQR 22-34), Mean age : } 29 \text {. }\end{array}$ & Cross Sectional \\
\hline 4 & Nangendo J, et al & 440 participants. Median age : 30 years & Cross Sectional \\
\hline 5 & Pando, et al & MSM : 600 participants, final : 404 & Cross Sectional \\
\hline 6 & Irarrazabal, et al & $\begin{array}{l}150 \text { participants. Men : } 40(27 \%) \\
\text { Women : } 110(73 \%)\end{array}$ & Cross Sectional \\
\hline 7 & Sarkar A, et al & $\begin{array}{l}202 \text { participants. Pregnant women. Median age : } 23 \\
\text { years }\end{array}$ & Cross Sectional \\
\hline 8 & Kurth $A E$, et al & 240 participants & $\begin{array}{l}\text { Descriptive Cross } \\
\text { Sectional }\end{array}$ \\
\hline 9 & Platteau Tom, et al & 983 participants & Cohort \\
\hline 10 & Marley, et al. & 1137 participants & $\begin{array}{l}\text { Descriptive Cross } \\
\text { Sectional }\end{array}$ \\
\hline 11 & Pant Pai, et al & 232 students & Cross Sectional \\
\hline 12 & Irarrazabal, et al & $\begin{array}{l}497 \text { Participants. Males : } 409 \text {, Females : } 88 \text {, Mean age } \\
31,36 \pm 11 \text { years }\end{array}$ & Cross Sectional \\
\hline 13 & $\begin{array}{l}\text { Xun Huanmiao, et } \\
\text { al }\end{array}$ & $\begin{array}{l}1137 \text { participants. MSM : } 371, \text { FSW : } 405, \text { VCT } \\
\text { Clients : } 361\end{array}$ & Cross Sectional \\
\hline 14 & Xu Yunan, et al. & 262 participants & Cross Sectional \\
\hline 15 & Donnel-Fink, et al & 1651 participants & $\begin{array}{c}\text { Randomized Controlled } \\
\text { Trial }\end{array}$ \\
\hline 16 & Jain Sachin, et al. & 1000 patients & $\begin{array}{l}\text { Descriptive Cross } \\
\text { Sectional }\end{array}$ \\
\hline 17 & $\mathrm{Ng} \mathrm{OT}$, et al & $\begin{array}{l}994 \text { participants. Known HIV-positive : } 200 \text {, Risk Clients } \\
\text { at the DSC clinic : } 598 \text {, Risk clients at the private clinics : } \\
196\end{array}$ & Cross Sectional \\
\hline 18 & Choko, et al & $\begin{array}{l}298 \text { participants, selected : } 283 . \text { Men : } 136 \text {, } \\
\text { Women : } 147\end{array}$ & Cross Sectional \\
\hline 19 & Gaydos, et al & $\begin{array}{l}564 \text { participants, selected : } 478 . \text { Male : ORT } \\
\text { (179), Female : ORT (254) }\end{array}$ & Cross Sectional \\
\hline 20 & Chen $\mathrm{Y} \mathrm{M}$, et al. & 172 participants & $\begin{array}{l}\text { Descriptive Cross } \\
\text { Sectional }\end{array}$ \\
\hline 21 & Sena, et al & 333 participants, eligible : 315 & Cross Sectional \\
\hline
\end{tabular}


Tabel 3. Results of selected studies according to the outcome review

\begin{tabular}{|c|c|c|c|}
\hline No & Author & Results & $\begin{array}{l}\text { Confidence } \\
\text { Interval }\end{array}$ \\
\hline 1 & Bradley, et al & Acceptability : $85 \%$ & N/A \\
\hline 2 & Sharma $P$, et al & $\begin{array}{l}\text { Like : } 91,2 \% \text {, Easy procedure : } 43 \% \text {, Maintains confidentiality : } 10 \% \text {, Non } \\
\text { Invasive : } 29 \% \text {, Quick acces to results : } 18 \%\end{array}$ & N/A \\
\hline 3 & Martin IB, et al & $\begin{array}{l}\text { Less Painfull : } 49(100) \text {, Easy of use }: 18(75) \text {, Faster time to results : } 4 \\
(33,3) \text {, Perceived accuracy : } 2(7,4)\end{array}$ & $95 \% \mathrm{Cl}$ \\
\hline 4 & Nangendo J, et al & $\begin{array}{l}\text { Pain free : } 399(90,7) \text {, No blood drawn : } 360(81,8) \text {, Short time to results : } \\
51(11,6) \text {, Privacy : } 19(4,3) \text {, Non-invasive : } 16(3,6) \text {, Reliable : } 37(8,4) \text {, } \\
\text { Easy sample collection : } 257(58,4) \text {, Convenient : } 180(40,9) \text {, Enable } \\
\text { Frequent testing : } 124(28,2)\end{array}$ & $95 \% \mathrm{Cl}$ \\
\hline 5 & Pando, et al & $\begin{array}{l}\text { Easy to do : } 70 \% \text {, Would to pay : } 74 \% \text {, Future the test frequently : } 77 \% \text {, } \\
\text { Self test : } 71 \%\end{array}$ & $\mathrm{~N} / \mathrm{A}$ \\
\hline 6 & Irarrazabal, et al & $\begin{array}{l}\text { EBP beliefs: } 59,53(7,78) \text {, HIV-related stigmatization: } 12,80(6,67) \text {, } \\
\text { Perceived importance of HIV testing: } 2,88(0,34) \text {, Perceived comfort } \\
\text { performing ORT: } 16,21(4,47) \text {, Perceived readiness to addopt ORT: } 14,51 \\
(3,67) \text {, Self Confidence : } 80 \% \text {, Strongly agreed importance : } 95 \%\end{array}$ & $95 \% \mathrm{Cl}$ \\
\hline 7 & Sarkar A, et al & $\begin{array}{l}\text { Acceptance : } 100 \% \text {, Like the test : } 98.0 \% \text {, Confident performed : } 95,5 \% \text {, } \\
\text { Easy to do : } 43,4 \% \text {, Quick results : } 27,3 \% \text {, Non-invasive : } 23,2 \% \text {, Self- } \\
\text { performed : } 4,1 \% \text {, Privacy : } 2,0 \% \text {, Benefited : } 90,6 \% \text {, Should be sold in } \\
\text { public : } 96,5 \% \text {, Would recommend: } 96,0 \%\end{array}$ & $95 \% \mathrm{Cl}$ \\
\hline 8 & Kurth $A E$, et al & Acceptability : $94 \%$ & $95 \% \mathrm{Cl}$ \\
\hline 9 & Platteau Tom, et al & Satisfied : $95,6 \%$, Would do so without hesitation : $86,9 \%$ & N/A \\
\hline 10 & Marley, et al. & $\begin{array}{l}\text { No blood : } 96,5 \% \text {, No pain : } 95,5 \% \text {, Convinient : } 58,4 \% \text {, Prefered home } \\
\text { testing: } 57,3 \%\end{array}$ & N/A \\
\hline 11 & Pant Pai, et al & $\begin{array}{l}\text { Agreement self test: } 100 \% \text {, Accepteability : } 81 \% \text {, Convenience : } 99 \% \text {, } \\
\text { Willingness to pay : } 74 \% \text {, Confident : } 87 \% \text {, Quick, non-invasive, easy to } \\
\text { do. }\end{array}$ & $95 \% \mathrm{Cl}$ \\
\hline 12 & Irarrazabal, et al & $\begin{array}{l}\text { Quicker access, More psychosocially positive, Faster result, Less } \\
\text { physically invasive, More practical }\end{array}$ & $95 \% \mathrm{Cl}$ \\
\hline 13 & $\begin{array}{l}\text { Xun Huanmiao, } \\
\quad \text { et al }\end{array}$ & $\begin{array}{l}\text { No blood drawn (MSM : } 55,3 \% \text {, FSW : } 75,8 \% \text {, VCT Clients : } 48,6 \% \text { ), No } \\
\text { Pain (MSM : } 37,5 \% \text {, FSW : } 75,8 \% \text {, VCT Clients : } 28,8 \% \text { ), Shorter time in } \\
\text { awaiting results (MSM : } 36,1 \% \text {, FSW : } 14,6 \% \text {, VCT Clients : } 39,5 \% \text { ), Had } \\
\text { not ever heard (MSM : } 27,1 \% \text {, FSW : } 51,4 \% \text {, } \\
\text { VCT Clients : } 24,4 \% \text { ), Self-test (MSM : } 28,1 \% \text {, FSW : } 15,6 \% \text {, VCT } \\
\text { Clients : } 32,5 \% \text { ) }\end{array}$ & $95 \% \mathrm{Cl}$ \\
\hline 14 & Xu Yunan, et al. & Preferred choice : $64,5 \%-87,0 \%$ & $95 \% \mathrm{Cl}$ \\
\hline 15 & Donnel-Fink, et al & Acceptability : $69 \%$, Test offer for the future : $93 \%$ & $95 \% \mathrm{Cl}$ \\
\hline 16 & Jain Sachin, et al & Quick results : 98,7\%, Acceptance : $74 \%$ & N/A \\
\hline 17 & $\mathrm{Ng} \mathrm{OT}$, et al & $\begin{array}{l}\text { Preferred : } 89 \% \text {, Convenient : } 98 \% \text {, Would purchase OTC : } 87,4 \% \text {, Quick } \\
\text { results : } 96 \% \text {, Easy to do and understand : } 95,8 \% \text {, Available OTC : } 90 \% \text {, } \\
\text { Necessary : } 74,9 \% \text {, Should be sold in public : } 89,3 \%\end{array}$ & $95 \% \mathrm{Cl}$ \\
\hline 18 & Choko, et al & $\begin{array}{l}\text { Acceptability : } 94,5 \% \text {, Not hard at all to do : } 98,5 \% \text {, Easy to do : } 98,5 \% \text {, } \\
\text { Willing to self test : } 95,9 \% \text {, Would recommended to friends, and family : } \\
100\end{array}$ & $95 \% \mathrm{Cl}$ \\
\hline 19 & Gaydos, et al & $\begin{array}{l}\text { Not painfull : } 98,8 \% \text {, Not unpleasant : } 97,5 \% \text {, Not hard at all : } 97,2 \% \text {, } \\
\text { Definitely test at home : } 87,5 \% \text {, Feel in control of own health : } 85,5 \% \text {, } \\
\text { Recommended to a friend : } 94,0 \%\end{array}$ & $95 \% \mathrm{Cl}$ \\
\hline 20 & Chen Y M, et al. & $\begin{array}{l}\text { Preference indicated : Convinience and peace of mind, less painful, } \\
\text { Quicker results, less stress, Easy, confidential, More accurate in a total of } \\
92 \%\end{array}$ & $\mathrm{~N} / \mathrm{A}$ \\
\hline 21 & Sena, et al & $\begin{array}{l}\text { Preferred: } 91,5 \% \text {, Test at home : } 73,4 \% \text {, Quick results / test results } \\
\text { immediately : } 89,9 \% \text {, Supported rapid testing in community : } 97,7 \%\end{array}$ & $95 \% \mathrm{Cl}$ \\
\hline
\end{tabular}


especially in pregnant women who will transmit to the babies they conceive as the results of research conducted by Pant Pai et al in India, where the author stated the importance of screening HIV tests on pregnant women as the last chance to prevention of mother-to-child HIV transmission (PMTCT), especially in settings where women do not receive adequate antenatal care. ${ }^{35}$

Of all the studies both analytic and descriptive studies that have been conducted in several countries, participants generally prefer HIV screening with oral rapid test compared to conventional tests. ${ }^{12,13,18}$ The main reason for the participants is due to the absence of pain from the blood-taking activity. ${ }^{14,15}$ Conventional HIV testing is done by taking blood samples which will be seen are HIV antibodies that can also be found in saliva. This is very helpful especially for people who are afraid of needles and do not want to be hurt by taking blood. Similar with results of the studies by Zachary et al which experience, oral fluid-based testing offers many advantages over blood-based testing, especially with self-testing on the horizon. ${ }^{36}$

The result is faster just waiting for about 20 minutes which we can see in the research results in the table above..$^{27,37,38}$ This tool is known as lateral flow immunoassays, which essentially coax analytes (HIV antibodies, in this case) up from cotton or the tip and into the yield area. Once they're in that area, two wall-like strips called membranes capture the analyte and show up as colored lines. ${ }^{6,38}$ This HIV antibody test detects cells created by the immune system (defense) in response to HIV infection. Most HIV tests detect the presence of HIV antibodies, not the HIV virus. ${ }^{6,37}$

This tool just enough to swabbing it between the gums and teeth. 6,37 The potential benefits of HIV self-testing include increased access to testing and early diagnosis for people living with HIV. ${ }^{39,40}$ People who do self-tests also experience greater comfort, autonomy, and privacy when testing, and this is possible provides options for individuals who do not use existing HTC services or those who do not have regular contact with (or access to) health services where HIV testing is offered. ${ }^{37,39}$ This ORT can be used privately at home so it is more appropriate for use by populations with high HIV prevalence. Thus, it is easier to access especially health workers in minimizing the impact of the increasing incidence of HIV infection in a region.

So far there are no risks associated with the use of ORT, there are no adverse events or hazards has been reported to date (for example there are no human rights violations from HIV self-testing abuse, or no reports of violence or self-harm. ${ }^{37}$

The oral fluid HIV test is very accurate. This test is FDA-approved with> $99 \%$ sensitivity and specificity claimed in many types of specimens, including oral fluids. In several studies, the OraQuick® In-Home HIV Test detected more than 91.7 percent of people infected with HIV, and 99.9 percent of people who were not infected with HIV. 6,37,41,42

In 2016, approximately 102 million HIV RDTs for professional use were reportedly procedure by the Global Fund, PEPFAR, UNICEF, and WHO. On June 27, 2017, the Charity Support Agreement between Bill\&Melinda Gates

The Foundation an OraSure Technologies Inc. were announced to reduce OraQuick $\circledast$ costs HIV Self-Test for public sector buyers in 50 low-income / heavy-burden countries. Funding to activate a more affordable price (\$2.00 ex-works) will consist of related support payments volume of products sold and reimbursement of certain related costs. $^{37}$ 
This test will also detect samples with predominantly IgM reactivity. The report of studies by Guillon et al detect IgM antibodies during an acute infection window period of approximately 20-25 days after infection. ${ }^{6}$

\section{CONCLUSIONS}

We concluded that high acceptance of Oral Rapid Test HIV, which in addition to easy, quick results and comfortable, also has high accuracy to match other conventional tests. Countries should make Oral Rapid Test as the HIVST available and determine over the counter for strategies to facilitate linkage, cost- effectiveness, and the pathway to create supportive policies will be needed to maximize the potential of introducing HIVST.

\section{REFERENCES}

1. Sheet F, HIV N, HIV N. 2017 GLOBAL HIV STATISTICS. 2018;(July):1-5.

2. Providers HIVT. Implementing HIV Testing in Nonclinical Settings A Guide for HIV Testing Providers. 2016.

3. Krause J, Subklew-sehume F, Kenyon C, Colebunders R. Acceptability of HIV self-testing : a systematic literature review. BMC Public Health. 2013;13(1):1. doi:10.1186/1471-2458-13-735.

4. Pai NP, Behlim T, Abrahams L, Vadnais C, Shivkumar S. Will an Unsupervised Self-Testing Strategy for HIV Work in Health Care Workers of South Africa? A Cross Sectional Pilot Feasibility Study. 2013;8(11). doi:10.1371/journal. pone.0079772.

5. Johnson CC, Kennedy C, Fonner V, et al. Review article Examining the effects of HIV self-testing compared to standard HIV testing services: a systematic review and meta-analysis. 2017. doi:10.7448/IAS.20.1.21594.

6. Guillon G, Yearwood G, Snipes C, Boschi D, Reed MR. Human anti-HIV IgM detection by the OraQuick ADVANCE Ò Rapid HIV 1 / 2 Antibody Test. 2018:1-11. doi:10.7717/peerj.4430.

7. Ekouevi DK, Kariyiare BG, Coffie PA, et al. Short report Feasibility and acceptability of rapid HIV screening in a labour ward in Togo. 2012:1-5. doi:10.7448/IAS.15.2.17380.

8. Mavedzenge SN, Baggaley R, Corbett EL. A Review of Self-Testing for HIV : Research and
Policy Priorities in a New Era of HIV Prevention. 2018;57(August). doi:10.1093/cid/cit156.

9. Loukou YG, Cabran MA, Yesse ZN, Adouko BMO, Lathro SJ. Performance of Rapid Tests and Algorithms for HIV Screening in Abidjan , Ivory Coast. 2014;13(1):35-39. doi:10.1177/2325957413488168.

10. Petticrew M, Shekelle $P$, Stewart LA, Group P. meta-analysis protocols ( PRISMA-P ) 2015 : elaboration. 2015;7647(January):1-25. doi:10.1136/bmj.g7647.

11. Munn Z, Moola S, Riitano D, Lisy K. Original Article The development of a critical appraisal tool for use in systematic reviews addressing questions of prevalence. 2014;3(3):123-128. doi:10.15171/ ijhpm.2014.71.

12. Bradley ELP, Vidot DC, Gaul Z, Sutton MY, Pereyra M. Acceptability of oral rapid HIV testing at dental clinics in communities with high HIV prevalence in South Florida. 2018;93:1-12.

13. Sharma P, Khan S, Behera J, Sarkar A, Mehra S, Shivkumar PV. HIV : Current Research Is it Feasible to Use an Oral-Fluid Based Rapid Test Facilitated by Frontline Workers to Improve HIV Screening of Pregnant Women in Indian Rural Settings ? 2018;3(1):1-5. doi:10.4172/25720805.1000127.

14. Martin IB, Williams V, Ferguson D, Read S. Performance of and preference for oral rapid HIV testing in The Bahamas. J Infect Public Health. 2017:6-9. doi:10.1016/j.jiph.2017.06.005.

15. Nangendo J, Obuku EA, Kawooya I, et al. Diagnostic accuracy and acceptability of rapid HIV oral testing among adults attending an urban public health facility in Kampala, Uganda. 2017:1-13.

16. Pando MA, Marone O, Barreda V, et al. High acceptability of rapid HIV self-testing among a diverse sample of MSM from Buenos. 2017:1-12.

17. Irarrázabal LP, Levy JA, Norr KF, et al. Predictors of readiness for oral rapid HIV testing by Chilean health care providers. 2016;40(3):363-370.

18. Sarkar A, Mburu G, Shivkumar PV, et al. Feasibility of supervised self-testing using an oral fluid-based HIV rapid testing method : a cross-sectional, mixed method study among pregnant women in rural India. 2016:1-11.

19. Kurth AE, Cleland CM, Chhun N, et al. Accuracy and Acceptability of Oral Fluid HIV Self-Testing in a General Adult Population in Kenya. AIDS Behav. 2016;20(4):870-879. doi:10.1007/s10461015-1213-9.

20. Platteau T, Fransen K, Apers L, Kenyon C. Swab2know: An HIV-Testing Strategy Using Oral Fluid Samples and Online Communication of Test Results for Men Who Have Sex With Men in Belgium Corresponding Author: 2015;17(9). doi:10.2196/jmir.4384.

21. Marley G, Kang D, Wilson EC, et al. Introducing rapid oral - fluid HIV testing among high risk populations in Shandong, China : feasibility and 
challenges. 2014:1-7.

22. Pai NP, Bhargava $M$, Joseph $L$, et al. Will an Unsupervised Self-Testing Strategy BeFeasible to Operationalize in Canada? Results from a Pilot Study in Students of a Large Canadian University. 2014;2014(c).

23. Irarrazábal LP, Ferrer L, Cianelli R, et al. HHS Public Access. 2016;33(6):427-432.

24. Xun H, Kang D, Huang T, et al. Factors Associated with Willingness to Accept Oral Fluid HIV Rapid Testing among Most-at-Risk Populations in China. 2013;8(11):1-8. doi:10.1371/journal. pone.0080594.

25. Xu Y, Zhang Z, Li D, et al. Willingness to Use the Oral Fluid HIV Rapid Test among Men Who Have Sex with Men in Beijing , China. 2013;8(5):1-8. doi:10.1371/journal.pone.0064652.

26. Donnell-fink LA, Arbelaez C, Collins JE, et al. NIH Public Access. 2013;61(July 2011). doi:10.1097/ QAI.0b013e31826a6d67..Acceptability.

27. Jain S, Lowman ES, Kessler A, et al. Original Contributions Seroprevalence Study Using Oral Rapid Hiv Testing. 2012;43(5). doi:10.1016/j. jemermed.2012.02.021.

28. Ng OT, Chow AL, Lee VJ, et al. Accuracy and User-Acceptability of HIV Self-Testing Using an Oral Fluid-Based HIV Rapid Test. 2012;7(9):310. doi:10.1371/journal.pone.0045168.

29. Choko AT, Desmond N, Webb EL, et al. The Uptake and Accuracy of Oral Kits for HIV Self-Testing in High HIV Prevalence Setting : A Cross-Sectional Feasibility Study in Blantyre, Malawi. 2011;8(10). doi:10.1371/journal.pmed.1001102.

30. Gaydos CA, Hsieh Y, Harvey L, Burah A, Won H. Will Patients "Opt In " to Perform Their Own Rapid HIV Test in the Emergency Department ? Ann Emerg Med. 2011;58(1):S74-S78. doi:10.1016/j. annemergmed.2011.03.029.

31. Mrcp MYC, Bilardi JE, Lee D. Australian men who have sex with men prefer rapid oral HIV testing over conventional blood testing for HIV. 2010:428-430.

32. Sena AC, Hammer JP, Wilson K, et al. Feasibility and Acceptability of Door-to-Door Rapid HIV Testing Among Latino Immigrants. AIDS Patient Care STDS. 2010;24(3).

33. US FDA. Premarket Approvals (PMAs) July 3 , 2012 Approval Letter, OraQuick In-Home HIV Test. 2012.
34. Pai NP, Balram B, Shivkumar S, et al. Head-tohead comparison of accuracy of a rapid pointof-care HIV test with oral versus whole-blood specimens : a systematic review and meta-analysis. Lancet Infect Dis. 2012;12(5):373-380. doi:10.1016/S1473-3099(11)70368-1.

35. Pai NP, Barick R, Tulsky JP, et al. Impact of Round-the-Clock, Rapid Oral Fluid HIV Testing of Women in Labor in Rural India. 2008;5(5). doi:10.1371/journal.pmed.0050092.

36. Zachary D, Mwenge L, Muyoyeta M, et al. Field comparison of OraQuick W ADVANCE Rapid HIV-1 / 2 antibody test and two blood-based rapid HIV antibody tests in Zambia.2012.

37. UNITAIDS Landscape T. HIV RAPID DIAGNOSTIC TESTS FOR SELF-TESTING. 2017.

38. Li S, Su S, Li S, Gao L, Cai Y, Fu J. A comparison of effectiveness between oral rapid testing and routine serum- based testing for HIV in an outpatient dental clinic in Yuxi Prefecture, China : a case - control study. 2017:1-8. doi:10.1136/bmjopen-2016-014601.

39. Manuscript A, Past HT. Home Testing Past, Present and Future: Lessons Learned and Implications for HIV Home Tests (A Review). 2015;18(July 2012):933-949. doi:10.1007/ s10461-013-0668-9.Home.

40. Hutchinson MK, Vandevanter N, Phelan J, et al. Feasibility of implementing rapid oral fluid HIV testing in an urban University Dental Clinic: a qualitative study. 2012.

41. Suntharasamai P, Martin M, Choopanya K, Vanichseni S. Assessment of Oral Fluid HIV Test Performance in an HIV Pre-Exposure Prophylaxis Trial in Bangkok, Thailand. 2015:1-9. doi:10.1371/journal.pone.0145859.

42. Choko AT, Taegtmeyer M, Macpherson P, et al. Initial Accuracy of HIV Rapid Test Kits Stored in Suboptimal Conditions and Validity of Delayed Reading of Oral Fluid Tests. 2016;5:6-13. doi:10.1371/journal.pone.0158107. 